\title{
Substantiation of the Results of Morphological Examination of the Urinary Bladder Wall in Experimental Diabetic Cystopathy
}

Nadiya Tokaruk

\begin{abstract}
Measurement of consumed water and daily diuresis proved the pathomorphological manifestations of streptozotocin-induced cystopathy in the experiment on rats according to the results of biochemical studies of blood and urine.

It is argued that the desquamation of cells in the transitional epithelium, its atrophy, stratification violation, and baring of the basal membrane are caused by a large volume of urine, which excessively stretches the urinary bladder, destroying the intercellular contacts of the urothelial layer. It is proved that primary hyperglycemia leads to widening of the lumen of the arterioles and moderate thickening of the basal membrane of the microhemovessels, and high chronic hyperglycemia - directly triggers the whole cascade of pathomorphological changes: on the $42^{\text {nd }}$ day of the experiment it causes vasoconstriction of the arterioles, and at the later terms - the secondary expansion of the arterioles and venules of the microcirculatory bed of UB (urinary bladder); is the cause of dystrophic changes of endothelial cells, further thickening and lamellar transformation of the basal membrane and plasma permeation of the perivascular connective tissue; causes the appearance of dark involutional myocytes with few organelles and sarcoplasm sequestration.

Hydropic dystrophy of smooth myocytes has been found to be associated with the hydration of blood plasma as a result of excessive polydipsia in diabetic animals, and vacuole dystrophy of urothelial cells, enlargement of their size and interstitial edema - with low specific urinary density due to the multiple fast increase of diuresis. It has been established that prolonged high glucosuria and decreased diuresis lead to a decrease in urothelial cell size, compaction of their cytoplasm and ultrastructural readjustment. The increase of the content of glycosylated hemoglobin during the experiment justified the appearance and increase of the sludge-syndrome.
\end{abstract}

Keywords

streptozotocin-induced diabetes, hyperglycemia, glucosuria, urothelium, diabetic cystopathy

Ivano-Frankivsk National Medical University, Ivano-Frankivsk, Ukraine

Corresponding author: hope88@i.ua

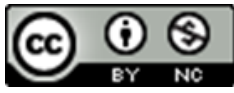

Copyright (C)Nadiya Tokaruk, 2019

\section{Problem statement and analysis of the latest research}

Diabetes mellitus (DM) is a metabolic disease that is manifested by chronically marked hyperglycemia that results from a deficiency of insulin secretion or a defect in the structure of insulin receptors. The level of glucose in the blood and urine is determined primarily for the detection or confirmation of DM, and the stability of its development is assessed according to the content of glycosylated hemoglobin $\left(\mathrm{HbA}_{1 \mathrm{C}}\right)$, which reflects average glycemia within 3 months before its determination [5]. The works in which the results of morphological studies of the structural components of the urinary bladder (UB) in streptozotocin-induced diabetes are consistent with the biochemical parameters of blood and 


\section{Substantiation of the Results of Morphological Examination of the Urinary Bladder Wall in \\ Experimental Diabetic Cystopathy - 2/12}

urine, the data of the study of water balance, are few $[10,27]$. In addition, there are no reports in which the results of biochemical observations are used to uncover the mechanisms of morphogenesis of diabetic cystopathy.

The social significance of this scientific theme is determined by the fact that diabetic cystopathy is a specific complication of DM, which is found in $30-87 \%$ of patients $[17,21,24,25,29,34,37,40]$ and affects both social and the economic status of patients [23, 27, 38, 39, 42], and DM tends to be widespread $[1,4,7,16,35]$. According to the International Diabetes Organization [30], the incidence of this disease increases at $50 \%$ every 10 years, and the total number of patients with DM will reach 642 million persons before 2040 [33, 44].

Objective of the study: to substantiate the pathomorphological patterns of the occurrence and course of streptozotocin-induced -induced cystopathy in rats.

\section{Materials and Methods}

In the study there were used 80 one-year-old Wistar rats (intact - 10, 10 experimental animals for each observation period and 4 - control ones). DM was caused by streptozotocin (60 mg/kg of body weight). Histological sections were stained with $H \& E$, and semifine sections - with methylene blue. Electron microscopic examination was performed according to generally accepted recommendations. To obtain objective numerical data, the area of the profile field (hereinafter referred to as - the area) of urothelial cells and their nuclei, the radius of the lumen and the thickness of the wall of the micro-hemovessels and the thickness of the basal membrane of the capillaries were determined.

Morphometry was performed in ImageJ version $1.47 \mathrm{t}$, and statistics - in R software version 3.0. Metabolic cameras were used to obtain diurnal diuresis of the rats. Blood glucose content was determined using "Accu-Chek Active" blood glucose monitor (Germany, Roche Diagnostics $\mathrm{GmbH}$ ), and in the material sampling for the morphologic study of UB, the glucose in urine and blood was determined using the glucose oxidase test. Urine $\mathrm{pH}$ was

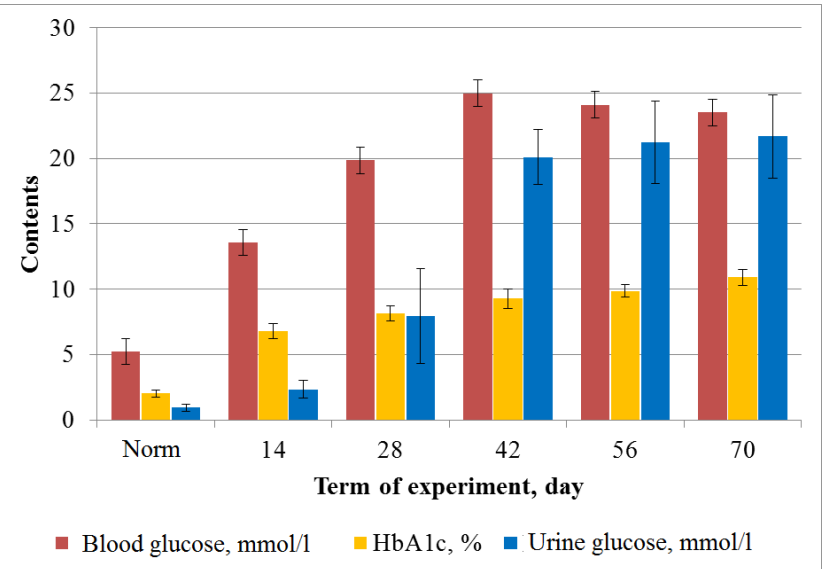

Figure 1. Dynamics of change of glucose level and $\mathrm{HbA}_{1 \mathrm{C}}$ content in blood and glucose concentration in urine normally and at the stages of the DM course.

measured using a portable $\mathrm{pH}$-meter "Checker 1" (Italy, Hanna Instruments).

\section{Results and Discussion}

The American Diabetes Association [18] considers the fasting blood glucose level to be higher than 7.0 $\mathrm{mmol} / \mathrm{l}$ and the $\mathrm{HbA}_{1 \mathrm{C}}$ content to be greater than $6.5 \%$ as the main criteria for the development of DM. For a clear comparison of the obtained by us two above-mentioned indices, as well as the glucose concentration in the urine, we've represented them in Fig. 1. The diagram shows that the level of glucose in the blood rapidly rises before the $42^{\text {nd }}$ day of the experiment and becomes greater than the control 4.7-fold and reaches the level of $24.98 \pm 2.16 \mathrm{mmol} / \mathrm{l}(\mathrm{p}<0.01)$, and during the $56^{\text {th }}$ $70^{\text {th }}$ days of the observation it remains as high as before. The same dynamics of the development of hyperglycemia is indicated by the authors who used Wistar rats in their studies $[11,13]$. Instead, in experiments using Sprague-Dawley rats, the glucose levels of 21-28 mmol/l in the blood of experimental rats were observed as early as on the $3^{\text {rd }}-14^{\text {th }}$ days of the experiment $[19,28]$. Although both lines of rats belong to the same species (Rattus norvegicus), Sprague-Dawley rats are more sensitive to diabetogenic factors.

Direct effect of hyperglycemia. Undoubtedly, 


\section{Substantiation of the Results of Morphological Examination of the Urinary Bladder Wall in Experimental Diabetic Cystopathy - 3/12}

hyperglycemia triggers the entire cascade of both pathophysiological and pathomorphological changes. The development of diabetic microangiopathy in the UB wall and, first of all, changes in the structural organization of the basal membrane (BM) of hemocapillaries, which depend on the duration and level of hyperglycemia, can be justified directly by hyperglycemia, as indicated by other researchers [41, 43]. Already on the $14^{\text {th }}$ day of the experiment there is a slight expansion of $\mathrm{BM}$, which on the $70^{\text {th }}$ day becomes more than 3 times thicker than the control. Its structural disorganization is marked on the $42^{\text {nd }}$ day of the experiment, and lamellar restructuring - on the $56^{\text {th }}-70^{\text {th }}$ days (Fig. 2). This reorganization of BM is caused by the non-enzymatic glycosylation of its proteins, which causes hyperglycemia, which increases during the development of DM $[6,20]$, which is argued in our experiment by the constant increase of the $\mathrm{HbA}_{1 \mathrm{C}}$ content. These processes lead at the last stages of the experiment to the increase of nonspecific permeability of BM, the appearance of interstitial edema and plasma permeation of the connective tissue. In addition, osmotically active glucose molecules of blood plasma cause a decrease in the size of endothelial cells as a result of their dehydration [3], and as a consequence, - the extension of inter-endothelial connections to such an extent that blood plasma proteins penetrate into the extravasal space.

Hyperglycemia has the direct influence on the change of the lumen of the small arteries and UB arterioles, only differently and at different terms. Thus, on the $14^{\text {th }}$ day of the experiment, the arterioles expand, but starting from the $28^{\text {th }}$ day - they narrow, and on the $42^{\text {nd }}$ day of the experiment, the spasmodic small arteries and arterioles, whose walls are usually swollen, are often found (Fig. 3). During the $56^{\text {th }}-70^{\text {th }}$ day of the streptozotocin-induced diabetes course, a moderate extension of arterioles is observed again. Such chronology of these changes is explained by the fact that hyperglycemia in different periods of the DM development activates different pathophysiological mechanisms. During the initial stages, moderate hyperglycemia stimulates the secretion of vasodilator mediators, among which the major one is nitric oxide, by the arterioles'

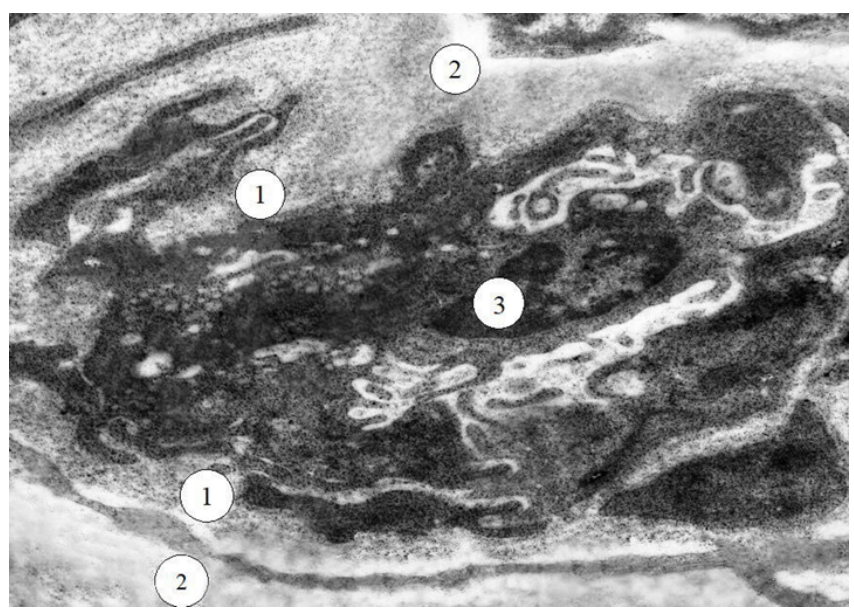

Figure 2. Destructive changes of the capillary wall on the $70^{\text {th }}$ day of diabetic cystopathy development. Electronic microphotograph. Magnification: $\times 9600$. Designations: 1 - lamellar basal membrane of the capillary; 2 - areas of plasma permeation; 3 - the nucleus of the endothelial cell.

endothelium [15], but chronic high hyperglycemia inhibits the synthesis of vasodilators [15, 22]. The extension of arterioles and small arteries during the last two terms of the experiment is associated with impaired vasoconstrictive sympathetic innervation of vessels [3]. In the prolonged significant hyperglycemia in the blood plasma an excessive amount of active glucose molecules circulates, they accumulate in the neurons, their processes and schwannocytes, where they are transported by GLUT 3 and GLUT 1 without insulin participation. The aldose reductase is activated, an osmotically active sorbitol is formed, which retains $\mathrm{Na}$ and water, leading to the destruction of the above-mentioned structures of nervous tissue $[2,3,7]$.

Using the same mechanism, with the accumulation of osmotically active sorbitol in endothelial cells, one can substantiate the swelling of the endothelium and thickening on the $42^{\text {nd }}$ day of the experiment of the wall of arterioles 1.4-fold, capillaries - 1.1-fold and venules - 1.2-fold.

Hyperglycemia is directly implicated in the growth of the number of dark involutional smooth myocytes in the UB wall since the $42^{\text {nd }}$ day of the development of streptozotocin-induced cystopathy. 

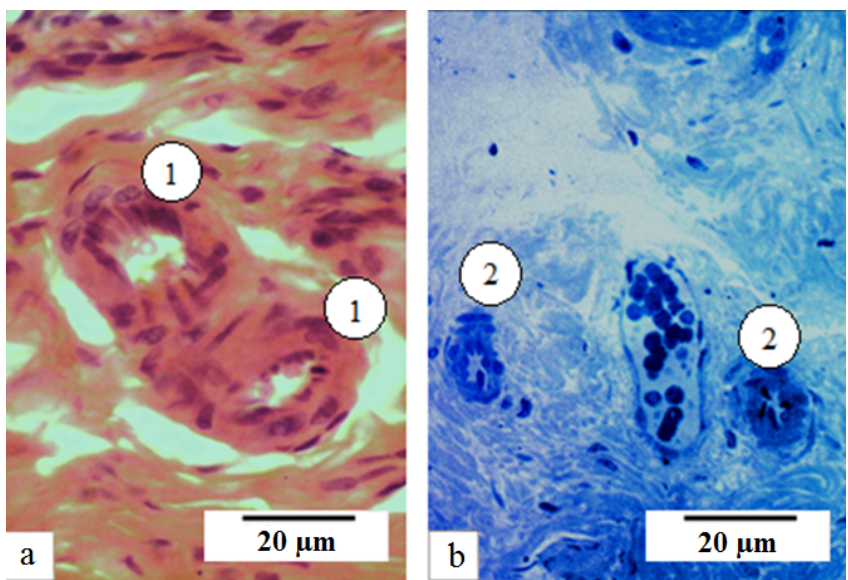

Figure 3. Vasoconstriction and edema of the wall of the intra-bladder arteries (a) and arterioles (b) on the $42^{\text {nd }}$ day of the development of diabetic cystopathy. Histological section, staining with hematoxylin and eosin (a). Semifine section, staining with methylene blue (b). Magnification: $\times 400$. Designations: 1 - artery; 2 - arteriole.

During this period, the blood plasma of diabetic rats becomes hypertensive as a result of an increase of blood glucose up to 24.11-24.98 $\mathrm{mmol} / \mathrm{l}$ and a simultaneous decrease compared to the $28^{\text {th }}$ day (1.31.6-fold) of polydipsia due to the reduced diuresis. Hypertensive plasma, whose osmotic pressure is higher than that of smooth myocytes, causes their dehydration. Our judgment is supported by the sequestration of smooth myocytes (Fig. 4), which is a consequence of coagulation (dry) necrosis, which occurs only in dehydrated tissues [14].

Impact of glucosuria. Glucosuria develops synchronously with hyperglycemia (Fig. 1). Urine glucose concentration progressively increases up to the $42^{\text {nd }}$ day of the experiment 22.8 -fold and equals $20.10 \pm 2.09 \mathrm{mmol} / \mathrm{l}(\mathrm{p}<0.01)$. On the $56^{\text {th }}$ and $70^{\text {th }}$ days of the development of diabetic cystopathy, glucosuria is the most pronounced. In these terms, the concentration of glucose in the urine is $21.26 \pm 3.15 \mathrm{mmol} / \mathrm{l}$ and $21.67 \pm 3.21 \mathrm{mmol} / \mathrm{l}$ and is greater than normal 22.61- and 22.81-fold (in all cases, $\mathrm{p}<0.01$ ). At the same time, blood glucose levels exceed the control only 4.5-4.8-fold. Such a dissonance in the development of hyperglycemia and glucosuria is also indicated by H.S.
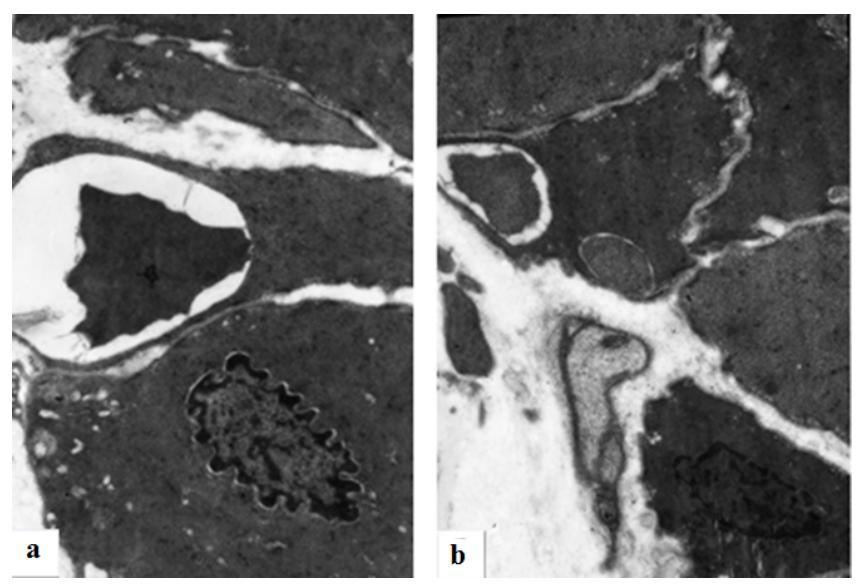

Figure 4. Dark involutional muscle cells in the wall of the urinary bladder with the areas of sequestration of smooth myocytes on the $70^{\text {th }}$ day of observation. Electronic microphotographs.

Magnification: $\times 8000$ (a); $\times 4000(b)$.

Boleyeva [2].

A decrease in the size of urothelial cells on the $42^{\text {nd }}-70^{\text {th }}$ days of the development of streptozotocininduced diabetes can be substantiated directly by glucosuria (Fig. 5): the areas of urothelial cells and their nuclei become moderately but statistically significantly smaller, respectively 1.1-1.2-fold $(\mathrm{p}<0.001)$ and 1.2-1.4-fold $(\mathrm{p}<0.01-0.001)$. The correctness of our judgment is substantiated by the following: 1) in these terms glucosuria is the highest (glucose concentration in urine is 21.3-21.7 mmol/l; $\mathrm{p}<0.01$ ), which significantly increases the specific density of urine; 2 ) at the same time, in comparison with the $28^{\text {th }}$ day, diuresis of diabetic rats decreases 1.7-1.8-fold $(\mathrm{p}<0.001)$, which further increases the osmotic pressure of urine; 3 ) the penetration of urine deep into the urothelium is facilitated by the destruction of the urothelial barrier; 4) hypertonic urine causes the release of water from urothelial cells according to concentration gradient [31]; 5) with each subsequent observation period there are more and more frequent dehydrated urotheliocytes, which look like osmophilic on the electron-diffraction photographs with a small number of organelles (Fig. 6).

Glycosylated hemoglobin. The dynamics of growth of $\mathrm{HbA}_{1 \mathrm{C}}$ content is different than that of 


\section{Substantiation of the Results of Morphological Examination of the Urinary Bladder Wall in \\ Experimental Diabetic Cystopathy - 5/12}

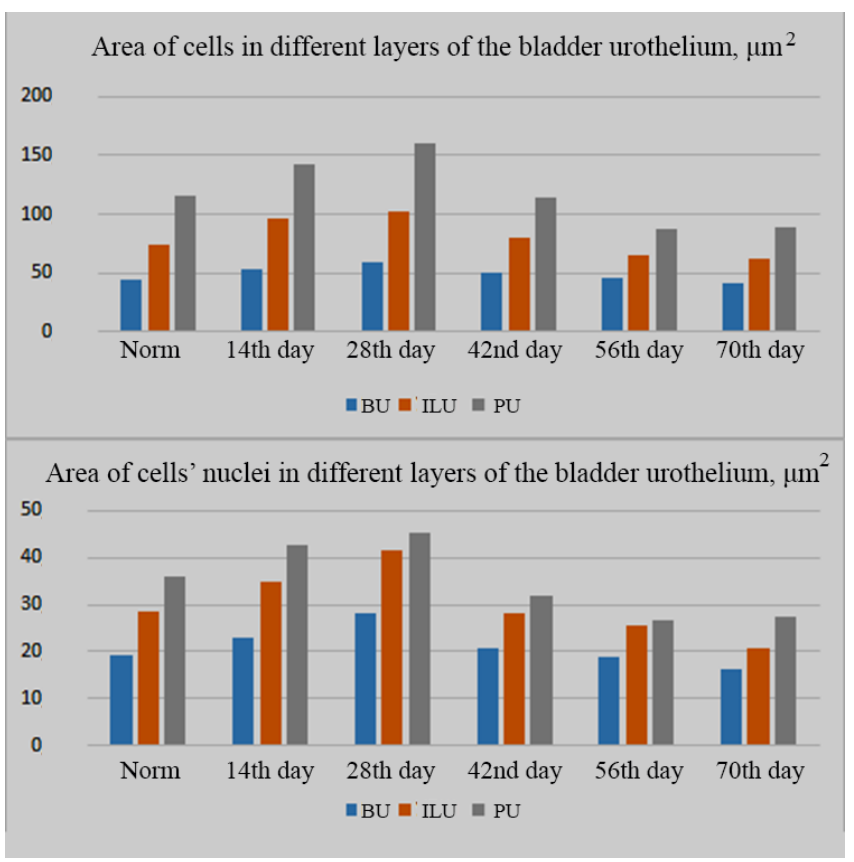

Figure 5. Change of the area of cells and their

nuclei of different layers of the transitional epithelium of the urinary bladder during the stages of development of streptozotocin-induced diabetes.

Designations: BU - basal urotheliocytes; ILU interstitial layer urotheliocytes; PU - superficial urotheliocytes.

hyperglycemia and glucosuria (Fig. 1). Its content increases 3.5 -fold as early as on the $14^{\text {th }}$ day of the DM development $(\mathrm{p}<0.01)$, and during the next experimental period increases with a deceleration, i.e., with each term, the increase in its percentage decreases, and on the $70^{\text {th }}$ day is $10.90 \pm 0.60 \%$ $(\mathrm{p}<0.001)$. According to the literature data, glycosylated hemoglobin alters the surface potential of erythrocytes and is directly related to their agglutination $[1,8]$. The results of our studies are consistent with those of the authors. Thus, on the $14^{\text {th }}$ day of diabetic cystopathy development, when $\mathrm{HbA}_{1 \mathrm{C}}$ is greater than the control 3.5-fold $(\mathrm{p}<0.01)$ - erythrocyte sludge occurs in single venules of the sub-urothelial microcirculatory bed, on the $28^{\text {th }}$ day, when the content of $\mathrm{HbA}_{1 \mathrm{C}}$ increases 4.1-fold $(\mathrm{p}<0.01)$ - sludge are present in many venules, on the $42^{\text {nd }}$ day the content of $\mathrm{HbA}_{1 \mathrm{C}}$ is higher than the control 4.6-fold $(\mathrm{p}<0.01)$ - sludge also occurs in arterioles and capillaries, and on the $56^{\text {th }}-70^{\text {th }}$
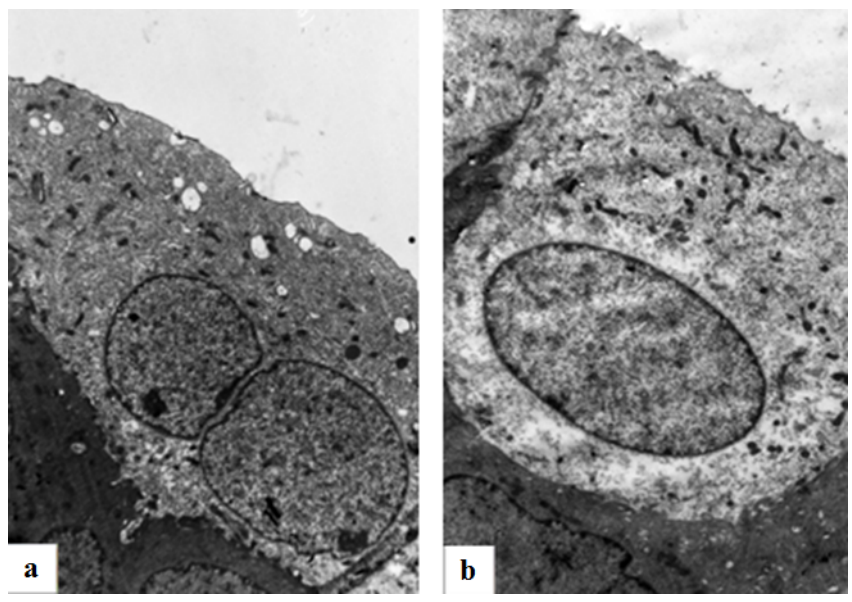

Figure 6. Light and dehydrated osmophilic bladder urothelial cells on the $56^{\text {th }}$ (a) and on the $70^{\text {th }}$ (b) days of experiment. Electron-diffraction photographs. Magnification: $\times 4000$ (a); $\times 4800$

(b).

days, when the content of $\mathrm{HbA}_{1 \mathrm{C}}$ is higher than the control 4.9-5.3-fold $(\mathrm{p}<0.001)$ - sludge is found in the micro-vessels of all UB membranes. We are convinced that the duration of hyperglycemia and the increase of the duration of $\mathrm{HbA}_{1 \mathrm{C}}$ action, which changes the superficial potential of an increasing number of erythrocytes, influence the generalization of the sludge-syndrome.

Violation of water balance. In DM, accompanied by osmotic diuresis and polyuria, which cause dehydration of organs and tissues and, as a result, polydipsia, it is important to determine the body's water balance, which is usually determined by the volume of consumed and secreted fluid. Consumed fluid is not only the consumed liquid, but also the one that comes with the food, and the secreted one - the fluid that is excreted by the kidneys, lungs, intestines and skin. Such calculations are difficult to perform in clinical settings, and in experimental ones - it is impossible. However, if the control and diabetic animals are kept in the same conditions and in the same qualitative and quantitative composition of the diet, then we can judge the water balance of the animal body according to the volume of drunk water and diuresis, which, in our opinion, is quite reasonable. In DM the dynamics of change of the indicated indices in comparison with control 


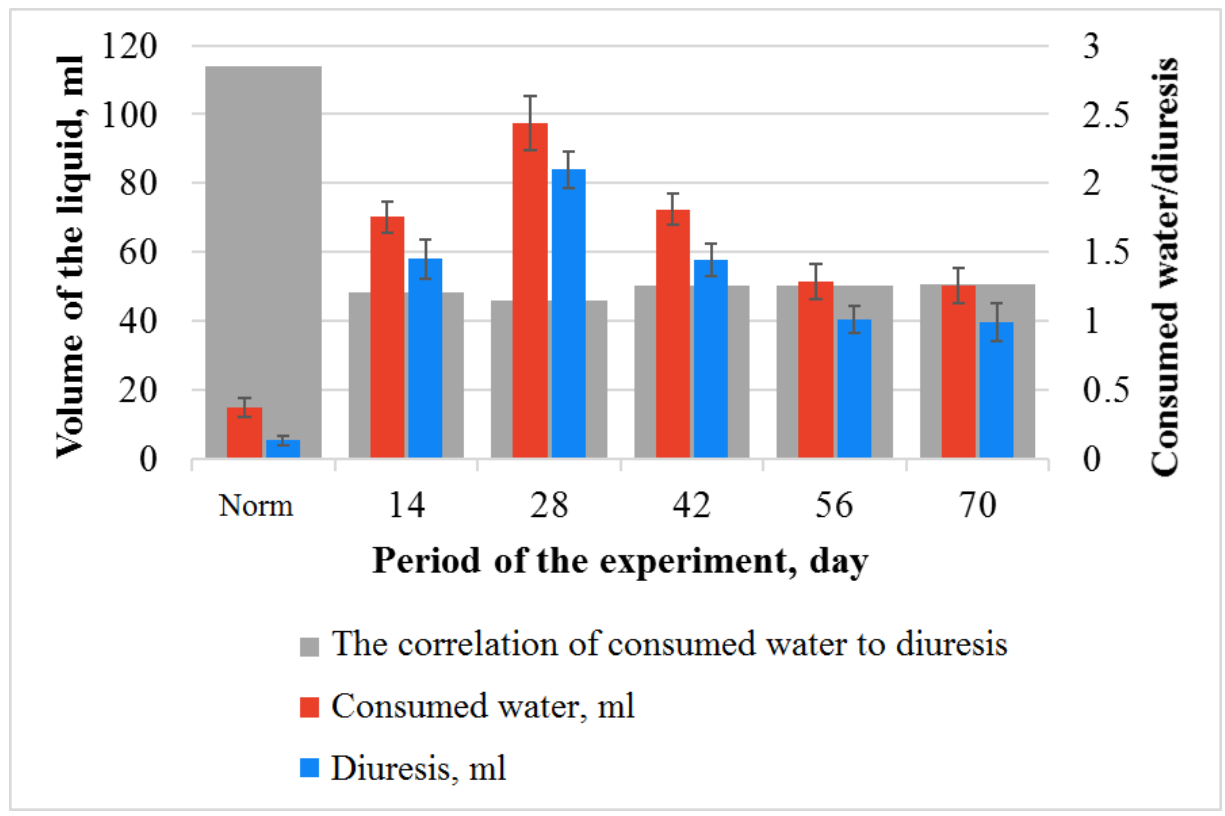

Figure 7. Water consumed per day, daily diuresis and their correlation in different stages of DM development.

is the following (Fig. 7; red and blue columns): on the $14^{\text {th }}$ and $28^{\text {th }}$ days of development of cystopathy they increase (in both cases $\mathrm{p}<0.01$ ), on the $42^{\text {nd }}$ and $56^{\text {th }}$ days - they decrease (in both cases $\mathrm{p}<0.001)$, and on the $70^{\text {th }}$ day - they do not change compared to the previous term $(\mathrm{p}>0.05)$. At the same time, on the $42^{\text {nd }}, 56^{\text {th }}$ and $70^{\text {th }}$ days of experiment, these indices remain greater than control: the volume of consumed water, respectively, is 5.8-; 4.98- and 4.9-fold, and diuresis - 13.6-; 11.1- and 11.1 -fold (in all cases, $\mathrm{p}<0.01$ ). Our results confirm the data, represented by other authors [32]. The increase in the concentration of primary urine leads to the decrease in diuresis in diabetic rats since the $42^{\text {nd }}$ day of the experiment [3]. In addition, during this period, microangiopathy manifests in our experiment, which, as it was determined by H.S. Boleyeva [2], reduces the filtration of water in the kidney glomeruli.

The above-mentioned indices do not give a holistic view of the water balance of the organism, but only indicate the degree of polyuria and polydipsia at the stages of DM development. We offer to use an index that characterizes the ratio of consumed water to diuresis (Fig. 7; gray wide columns). When the excretion of fluid exceeds its inflow into the body (negative water balance) and dehydration develops - this index decreases. On the contrary, when fluid intake exceeds diuresis (positive water balance) and hyperhydration develops - this rate increases. This index is integrative and gives a certain holistic view of the body's water balance. In our experiment, this rate is normally $2.85 \pm 0.25$. In Fig. 7 it is clearly shown that in diabetic rats this indicator at all stages of the course of DM is reduced by about half. This clearly indicates that water balance violation in streptozotocin-induced diabetes occurs from the first term and does not recover during the experiment.

Changes in the water balance can explain a number of common pathologic processes that were observed during the development of streptozotocininduced cystopathy. First of all, this concerns the desquamation of urothelial cells, which was also observed in experimental DM by other researchers [28] and which is a consequence of the action of hydrostatic pressure of increasing urine volume. Thus, on the $14^{\text {th }}$ day of observation, when the volume of urine increases up to $(58.0 \pm 5.8) \mathrm{ml}$ per day, only umbrellate cells exfoliate and wedge-shaped ruptures of the urothelium reaching its intermediate layer are observed (Fig. $8 \mathrm{a}$ and $8 \mathrm{~b}$ ). On the $28^{\text {th }}$ day 


\section{Substantiation of the Results of Morphological Examination of the Urinary Bladder Wall in Experimental Diabetic Cystopathy - 7/12}
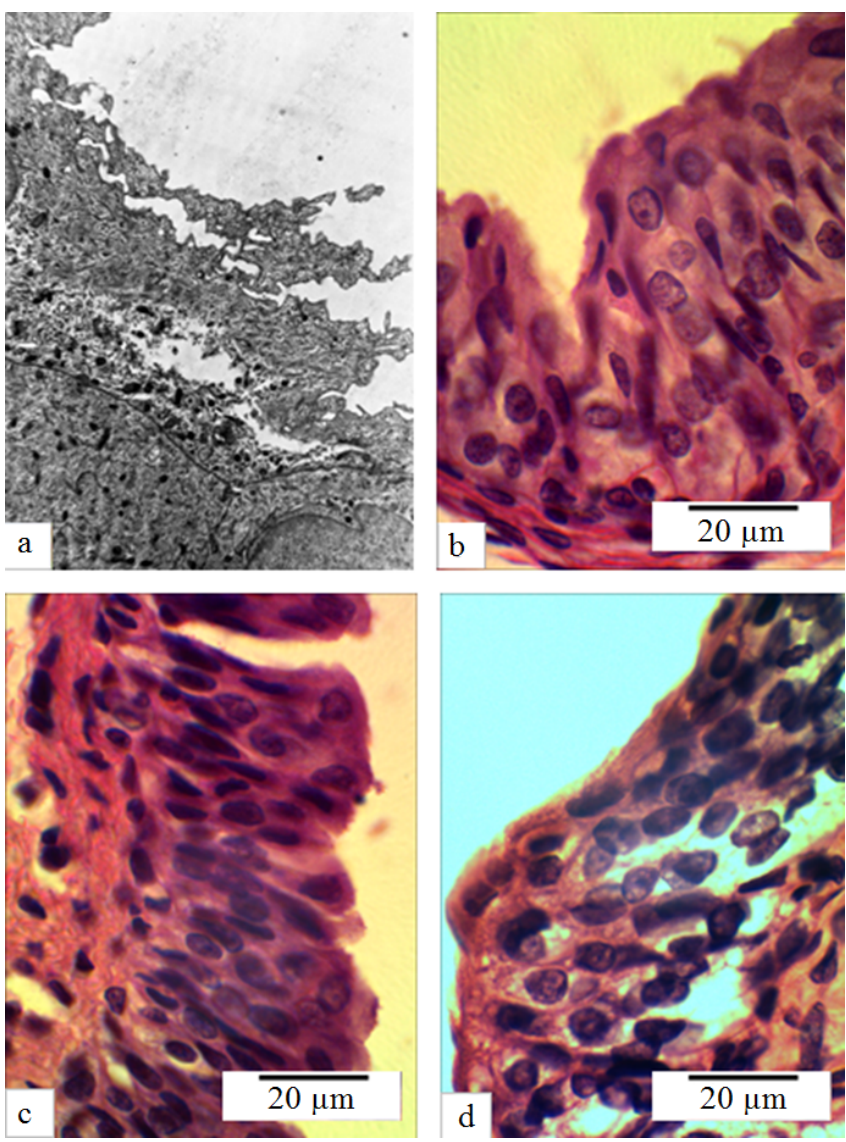

Figure 8. Desquamation of cells of the transitional epithelium of the urinary bladder on the $14^{\text {th }}(\mathrm{a}, \mathrm{b})$ and $28^{\text {th }}(\mathrm{c}, \mathrm{d})$ days of development of streptozotocin-induced cystopathy. Electron-diffraction photograph (a). Histological sections were stained with hematoxylin and eosin (b, c, d). Magnification: $\times 4800$ (a); $\times 400(b, c, d)$.

of the experiment the volume of urine increases up to $(84.0 \pm 5.4) \mathrm{ml} /$ day - the wedge-shaped ruptures of the transitional epithelium in many areas reach the BM, and in other areas its total desquamation is noted (Fig. 8c and $8 d$ ). Since the $42^{\text {nd }}$ day of the experiment, diuresis in diabetic rats began to decrease, but urothelium desquamation continued to manifest. The reason for this is a shift in the reaction of urine to acidic (urine $\mathrm{pH}$ decreases up to the level of $5.53 \pm 0.44$ ), which contributes to the rupture of the intercellular contacts of the transitional epithelium of the UB. Actually desquamation of urothelial cells and aciduria lead to the violation of the layered structure (Fig. 9a) and baring of the basal membrane (Fig. 9b) of the urothelium.
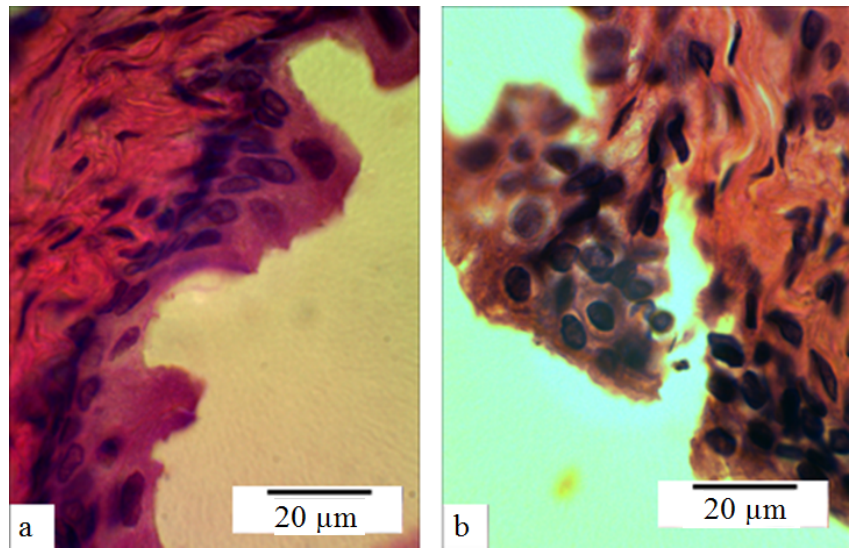

Figure 9. Violation of the layered structure (a) and baring of the basal membrane (b) of the urothelium on the $42^{\text {nd }}$ (a) and $56^{\text {th }}$ (b) days of the experiment. Microphotographs. Staining with hematoxylin and eosin. Magnification: $\times 400$.

Development of hydropic dystrophy. Water imbalance, which occurs on the background of hyperglycemia, polydipsia and glucosuria, one can substantiate the development of hydropic dystrophy of urothelial cells and smooth UB myocytes, which appear already on the $14^{\text {th }}$ day of the experiment and are manifested on the $28^{\text {th }}$ day. The development of vacuolar dystrophy of urothelial cells (Fig. 10) occurs as follows: 1) hyperglycemia causes osmotic diuresis, which is manifested by a decrease of water reabsorption in the kidney nephrons [3]; 2) as a result of excessive accumulation of water and repeated increase of the rate of diuresis, urine becomes of low specific density [2]; 3) after damage of the urothelial cell barrier of the UB due to desquamation of the urothelial cells, the components of the urine, in particular water, move to the deeper layers of the transitional epithelium [20]; 4) from the hypotonic urine, water molecules move in the direction of higher osmotic pressure, that is, inside the urothelial cells; 5) according to the literature, the active transport of water from the urine to the urothelial cells can also be performed by aquaporins (AQPs) [26] and urea transporters (UTs) [26, 36].

We believe that the cause of the development of vacuolar dystrophy of UB smooth myocytes (Fig. 11) 


\section{Substantiation of the Results of Morphological Examination of the Urinary Bladder Wall in Experimental Diabetic Cystopathy - 8/12}
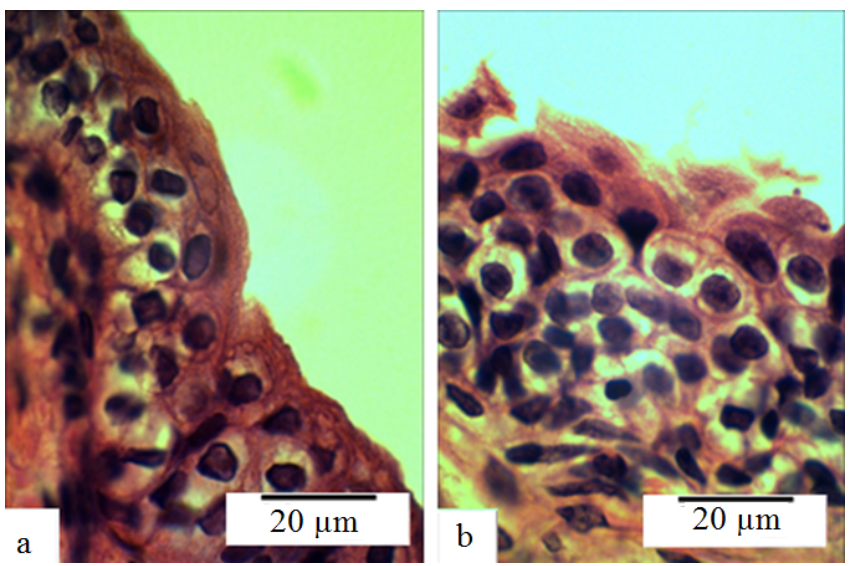

Figure 10. Vacuolar dystrophy of urothelial cells on the $14^{\text {th }}$ (a) and $28^{\text {th }}$ (b) days of development of diabetic cystopathy. Microphotographs. Staining with hematoxylin and eosin. Magnification: $\times 400$.

is a high degree of hydration of the blood plasma of diabetic rats, since they drink 5.1-7.6-fold more water than control ones. This water enters the bloodstream. There is no doubt that in this case the osmotic pressure of the blood plasma is lower than in the cells. The income of such blood plasma to the muscular membrane of the UB is facilitated by diabetic microangiopathy, which in our experiment on the $14^{\text {th }}-28^{\text {th }}$ days is manifested by the expansion of arterioles and erythrocyte sludge in the venules, which leads to an increase of hydrostatic blood pressure in the capillaries and outcome of blood plasma and the appearance of hypotonic interstitial edema, from which the water according to the gradient concentration enters the smooth myocytes [3]. However, there are works in which violation of water-mineral exchange in UB myocytes and the development of vacuolar dystrophy in them are associated not with hypotonic interstitial edema, but with excessive stretching of its wall for various reasons $[9,12]$. It is possible that such a mechanism for the development of hydropic dystrophy in the muscular tissue of the UB is acceptable in our experiment, because in any DM, excessive stretching of the UB occurs constantly as a result of significant polyuria.
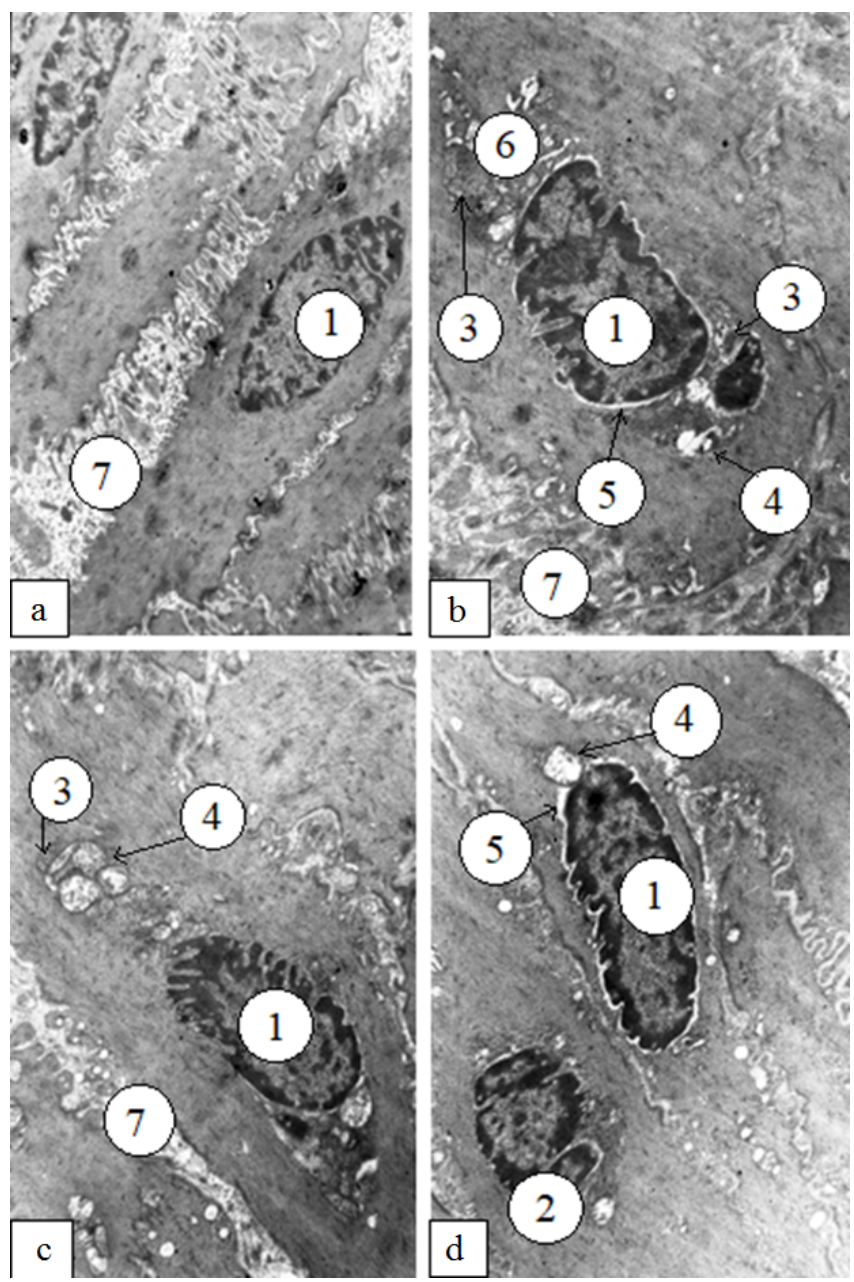

Figure 11. Electron-microscopic manifestations of hydropic dystrophy of smooth myocytes of urinary bladder on the $14^{\text {th }}(\mathrm{a}), 28^{\text {th }}(\mathrm{b}, \mathrm{c})$ and $42^{\text {nd }}$

(d) days of development of diabetic cystopathy. Electronic microphotographs. Magnification: $\times 6400$. Designations: $1-$ nuclei, 2 - apoptotic bodies, 3 - mitochondria of normal structure, 4 swollen mitochondria with destroyed ridges, 5 expansion of the perinuclear space, 6 - expansion of the endoplasmic reticulum and Golgi complex, 7 - expansion of the intercellular space.

\section{Conclusions}

1. The main morphological signs of diabetic cystopathy - cell desquamation, stratification disorders, atrophy and baring of basal membrane of urothelium - are caused by the large volume of urine due to osmotic diuresis, triggered by hyperglycemia, and which is exces- 
sively stretched.

2. Primary hyperglycemia in the early stages of the development of streptozotocin-induced diabetes is directly implicated in the expansion of the lumen of the arterioles and moderate thickening of the basal membrane of microhemovessels. High chronic hyperglycemia is the obvious cause: vasoconstriction of arterioles on the $42^{\text {nd }}$ day of the experiment, and in the later stages - secondary expansion of arterioles and venules; an increase of dystrophic changes in endothelial cells; significant thickening and lamellar basal membrane; plasma permeation of perivascular connective tissue; appearance of dark involutional myocytes with few organelles and sarcoplasm sequestration.

3. Hydropic dystrophy of smooth myocytes is associated with the hydration of blood plasma as a result of excessive polydipsia in diabetic animals, and vacuole dystrophy of urothelial cells, enlargement of their size and interstitial edema - with low specific urinary density due to the repeated multiple rapid increase of diuresis. Prolonged high glucosuria on the background of a slight decrease of diuresis leads to a decrease of the size of urothelial cells, compaction of their cytoplasm and ultrastructural readjustment.

4. Rheological disorders of the blood, which are morphologically manifested by the appearance of erythrocyte sludge, first in the venular department of the sub-urothelial microcirculatory bed, then in the arterioles and capillaries, and then by generalization of sludge syndrome in the hemovessels of all the membranes of the urinary bladder are explained by prolonged baring to glycosylated hemoglobin.

\section{Prospects of Further Researches}

In the future, a number of studies will be planned to study urothelium, muscular membrane, intra-organ hemovessels of urinary bladder in experimental type II diabetes mellitus.

\section{References}

[1] Blyshchak NB. Structural restructuring of the submandibular salivary glands of the rat and their vascular bed under experimental diabetes mellitus. Visnyk morfolohiyi. 2014; 20 (1): 129-132.

[2] Boleyeva HS. Regulatory changes in kidney arteries in rats in type I diabetes mellitus: author. diss. for candidate of biol. sciences: specialty 03.03.01 "Fiziologiya". 2013; 24.

[3] Hanonh VF. Human physiology: a textbook. Lviv: Bak. 2002; 784.

[4] Holovatskyy AS. Microstructural skin changes in experimental diabetes mellitus. Visnyk Ukrayinskoyi medychnoyi stomatolohichnoyi akademiyi. 2015; 15 (4): 220-223.

[5] Korolev VA. Diagnosis of hyperglycemia in the clinic. Laboratornaya diagnostika. 2010; 54 (4): 10-21.

[6] Krutikov ES. Changes in capillaroscopy in patients with type I diabetes mellitus in the development of chronic complications. Mezhdunarodnyy endokrinologicheskiy zhurnal. 2014; 2 (58): 40-44.

[7] Kuzmin IV, Shabudina NO. Pathogenetic basis for the development of diabetic cystopathy. Experimental and clinical urology. 2014; 4: 9298.

[8] Paltov YeV, Kryvko YuYa, Fik VB, et al. Morphofunctional changes of vascular walls of the hemomicrocirculatory bed against a background of diabetic parodontopathies (literature review). Eksperymentalna ta klinichna fiziolohiya i biokhimiya. 2008; 42 (2): 81-86.

[9] Nepomniashchikh LM, Lushnikova LYe, Neymark AI. Remodeling of the muscular membrane (detrusor) of a hyperactive urinary bladder in prostatic hyperplasia. Byulleten eksperimentalnoy biologii i meditsiny. 2012; 153 (5): 742-747. DOI: https://doi. 
org/10.1007/s10517-012-1825-2

[PMid:23113284]

[10] Rozhivanov RV, Akimova AN, Dubsky $\mathrm{SA}$, et al. Peculiarities of diseases of the genitourinary system in diabetes mellitus. Diagnostika, kontrol i lecheniye. 2009; 2: 40-45. DOI: https://doi.org/10. $14341 / 2072-0351-5396$

[11] Pokotylo PB. Angioarchitectonics of rat kidney normally and experimental diabetes mellitus: auth. diss. for the scientif. degree of Candidate of med. sciences: specialty 14.03.01 "Normal Anatomy". Lviv: 2013; 19.

[12] Nepomniashchikh LM, Lushnikova LYe, Neymark AI, et al. The role of structural-functional changes in the smooth muscle cells of the detrusor and prostate gland in the development of hyperactive urinary bladder. Fundamentalnyye issledovaniya. 2012; 5: 68-73.

[13] Savka II. Morphology of the rat egg and its vascular bed normally and in streptozotocininduced -induced diabetes mellitus: auth. diss. for the scientif. degree of cand. of med. sciences: specialty 14.03.01 "Normal Anatomy". Lviv: 2014; 20.

[14] Shlopov VH. Pathological anatomy: textbook. Vinnytsia: Nova Knyha. 2004; 768.

[15] Yarek-Martynova IR, Shestakova MV. Diabetes mellitus and endothelial dysfunction. Sakharnyy diabet. 2004; 2: 48-52. DOI: https://doi.org/10.14341/ 2072-0351-5609

[16] Alberti KG, Zimmet P. Global burden of disease-where does diabetes mellitus fit in? Nat Rev Endocrinol. 2013; 9(5): 258260. DOI: https: / / doi .org/10.1038/ nrendo.2013.54 [PMid:23478328]

[17] Yonekubo S, Tatemichi S, Maruyama K, Kobayashi M. Alpha1A-adrenoceptor antagonist improves underactive bladder associated with diabetic cystopathy via bladder blood flow in rats. BMC Urology. 2017; 17: 64-72. DOI: https://doi.org/10.1186/ s12894-017-0256-9 [PMid:28835278 PMCid:PMC5569480]

[18] American Diabetes Association. Classification and diagnosis of diabetes. Diabetes Care. 2015; 38(1): 8-16. DOI: https : / / doi .org/10 . 2337/dc15-S005 [PMid:25537714]

[19] Atalik KE. Diabetes mellitus- and cooling-induced bladder contraction: an in vitro study. J Smooth Mus Res. 2010; 46(4): 175183. DOI: https: //doi.org/10.1540/jsmr.46.175 [PMid:20859065]

[20] Birder LA, Andersson KE. Urothelial signaling. Physiol Rev. 2013; 93: 653680. DOI: https://doi .org/10.1152/ physrev.00030.2012 [PMid:23589830 PMCid:PMC3768101]

[21] Choi H, Bae1 JH, Oh CY, et al. Clinical Efficacy of Solifenacin in the Management of Diabetes Mellitus-Associated Versus Idiopathic Overactive Bladder Symptoms: A Multicenter Prospective Study. Int Neurourol J. 2018; 22; 51-57. DOI: https://doi. org/10.5213/inj.1834982.491 [PMid:29609421 PMCid:PMC5885131]

[22] Oikawa J, Ukawa S, Ohira H, et al. Diabetes mellitus is associated with low secretion rates of immunoglobulin in saliva. J Epidemiol. 2015; 25(7): 470-474. DOI: https:// doi.org/10.2188/jea.JE20140088 [PMid:26094794 PMCid:PMC4483372]

[23] Wittig L, Carlson KV, Andrews JM, et al. Diabetic bladder dysfunction: a review. Urology. 2019; 123:1-6. DOI: https://doi.org/ $10.1016 / j$.urology. 2018.10 .010 [PMid:30352207]

[24] Inouye BM, Hughes FM, Jin H, et al. Diabetic bladder dysfunction is associated with bladder 
inflammation triggered through hyperglycemia, not polyuria. Research and Reports in Urology. 2018; 10: 219-225. DOI: https : //doi.org/10.2147/RRU.S177633

[PMid:30533402 PMCid:PMC6247963]

[25] Ellenbroek JH, Inan EA, Mitchel MC. A systematic review of urinary bladder hypertrophy in experimental diabetes: Part 2. Comparison of animal models and functional consequences. Neurourology and Urodynamics. 2018; 37: 2346-2360. DOI: https://doi .org/10 . 1002 / nau . 23786 [PMid:30152546]

[26] Spector DA, Wade JB, Dillow R, et al. Expression, localization, and regulation of aquaporin-1 to -3 in rat urothelia. Am J Physiol Renal Physiol. 2002; 282:1034 - 1042. DOI: https://doi.org/ 10.1152 / a jprenal .00136.2001 [PMid:11997319]

[27] Hill SR, Fayyard SR, Jones GR. Diabetes mellitus and female lower urinary tract symptoms: a review. Neurourol Urodynam. 2008; 27:362368. DOI: https: / / doi .org/10.1002/ nau. 20533 [PMid:18041770]

[28] Hanna-Mitchell AT, Ruiz GW, Danechgari F, et al. Impact of diabetes mellitus on bladder uroepithelial cells. Am J Physiol Regul Integr Comp Physiol. 2013; 304(2): 8493. DOI: https://doi.org/10.1152/ ajpregu.00129.2012 [PMid:23174855 PMCid:PMC3543662]

[29] Inan EA, Ellenbroek JH, Michel MC. A systematic review of urinary bladder hypertrophy in experimental diabetes: Part I. Streptozotocin-induced -induced rat models. Neurourology and Urodynamics. 2018; 37:1212-1219. DOI: https://doi .org/ $10.1002 /$ hau. 23490 [PMid:29392751]

[30] International Diabetes Federation. IDF diabetes atlas. Brussels: International Diabetes Federation. 2015; 144.
[31] Khandelwal P, Abraham SN, Apodaca G. Cell biology and physiology of the uroepithelium. Am J Physiol Renal Physiol. 2009; 297(6):1477-1501. DOI: https://doi.org/10.1152/ a jprenal . 00327.2009 [PMid:19587142 PMCid:PMC2801337]

[32] Liu G, Daneshgari F. Temporal diabetesand diuresis-induced remodeling of the urinary bladder in the rat. Am J Physiol Regul Integ Comp Physiol. 2006; 291: 837843. DOI: https: / / doi.org/10.1152/ a jpregu. 00917.2005 [PMid:16513765]

[33] Danaei G, Finucane MM, Lu Y, et al. National, regional, and global trends in fasting plasma glucose and diabetes prevalence since 1980: systematic analysis of health examination surveys and epidemiological studies with 370 country-years and 27 million participants. Lancet. 2011; 378(9785): 3140. DOI: https://doi.org/10.1016/ S0140-6736(11) 60679-X

[34] Li WJ, Xu M, Gu M, et al. Poly(ADP-ribose) polymerase inhibition restores bladder function by suppressing bladder apoptosis in diabetic rats. Int J Clin Exp Pathol. 2017;10(4): 44514460 .

[35] Srivastava PK, Srivastava S, Singh AK, et al. Role of ayurveda in management of diabetes mellitus. Inter Res J Pharm. 2015; 6(1): 8-9. DOI: https://doi.org/10.7897/ $2230-8407.0613$

[36] Spector DA, Yang Q, Wade JB. High urea and creatinine concentrations and urea transporter in mammalian urinary tract tissues. Am J Physiol Renal Physiol. 2007; 292(1): 467-474. DOI: https://doi.org/ 10.1152 /a jprenal.00181.2006 [PMid:16849692]

[37] Yang S, Wang D, Cao X, et al. Store operated calcium channels are associated with diabetic cystopathy in streptozotocin-induced induced 
diabetic rats. Molecular Medicine Reports. 2018; 17: 6612-6620. DOI: https:// doi.org/10.3892/mmr.2018.8723

[PMid:29532875 PMCid:PMC5928646]

[38] Han JS, Min YS, Kim GH, et al. The change of signaling pathway on the electrical stimulated contraction in streptozotocin-induced -induced bladder dysfunction of rats. Korean J Physiol Pharmacol. 2018; 22(5): 577584. DOI: https://doi.org/10.4196/ kjpp.2018.22.5.577 [PMid:30181704 PMCid:PMC6115354]

[39] He P, Zhou XZ, Shen WH, et al. The function of hyperpolarization-activated cyclic nucleotide-gated channel in diabetic cystopathy. European Review for Medical and Pharmacological Sciences. 2018; 22: 6575-6582.

[40] Han JS, Kim SJ, Nam Y, et al. The Inhibitory Mechanism on Acetylcholine-Induced Contraction of Bladder Smooth Muscle in the Streptozotocin-induced -Induced Diabetic Rat. Biomol Ther. 2019; 27(1):101106. DOI: https://doi.org/10.4062/ biomolther.2018.136 [PMid:30419634 PMCid:PMC6319557]

[41] Lee SE, Ma W, Rattigan EM, et al. Ultrastructural features of retinal capillary basement membrane thickening in diabetic swine. Ultrastruct Pathol. 2010; 34(1): 35-41. DOI: https://doi.org/10.3109/ 01913120903308583 [PMid:20070152 PMCid:PMC3085508]

[42] Klee NS, McCarthy CG, Lewis S, et al. Urothelial Senescence in the Pathophysiology of Diabetic Bladder Dysfunction - A Novel Hypothesis. Hypothesis and Theory. 2018; 5. DOI: https://doi.org/10.3389/ fsurg. 2018.00072 [PMid:30564582 PMCid:PMC6288180]

[43] Vojtková J, Čiljaková M, Bánovčin P. Diabetic microangiopathy - etiopathogenesis, new possibilities in diagnostics and management.
Microangiopathy. InTech. 2012; 37- 66. DOI: https://doi.org/10.5772/31103

[44]

Zheng Y, Ley SH, Hu FB. Global aetiology and epidemiology of type 2 diabetes mellitus and its complications. Nature Reviews Endocrinology. 2017. DOI: https://doi . org/10.1038/nrendo.2017.151

[PMid:29219149]

Received: 2019-06-27

Revised: 2019-09-22

Accepted: 2019-09-27 